\title{
Socio-cultural structure of transmigrant communities in the Salimbatu Area for accelerating regional development of Bulungan Regency, Indonesia
}

\author{
Sindhung Wardana ${ }^{1}$, Hayati Sari Hasibuan ${ }^{1}$, and Herdis Herdiansyah ${ }^{1 *}$ \\ ${ }^{1}$ School of Environmental Science, Universitas Indonesia, Central Jakarta 10430, Indonesia
}

\begin{abstract}
Bulungan Regency as the capital of North Kalimantan Province needs accelerated development to realize its vision as an industrial-based food center. Among the aspects that still need to be worked out are the availability of human resources (HR) as the main driver of the regional economy. It is hoped that the presence of the Transmigrant Community with an agricultural background in the Salimbatu area can make a positive contribution to efforts to accelerate development in Bulungan Regency. By using a combination of literature review study methods reinforced with GIS analysis, this study seeks to reveal the socio-cultural structure of the people in the Salimbatu Transmigration Area and its contribution to improving the agricultural sector to accelerate regional development. The results obtained from this study indicate that the presence of the Transmigrant Community in the Salimbatu area has a proportion where $54.35 \%$ of them are native Bulungan people, while the remaining $45.65 \%$ are migrants through the Transmigration program. The socio-cultural proportion of the peasant community through the transmigration program to strengthen the regional economy in the agricultural sector in Bulungan Regency currently has not had an optimal impact.
\end{abstract}

\section{Introduction}

Equitable development between rural and urban areas is very important in reducing inequality in Indonesia [1]. The excessive concentration of the economy in Java has left other regions behind. On the other hand, many resources are absorbed only to support economic activities in Java because they are converted by industries located in Java and / or exported to international markets. In this unbalanced situation, it is necessary to shift economic activities outside Java to encourage optimal resource utilization and free Java from the potential for increasing socio-economic problems [2].

Indonesia's condition, which is heavily influenced by overpopulation in Java and Bali and the lack of human resources in many other areas, demands internal migration as a solution to the economic and social problems that arise as a result of this phenomenon.

\footnotetext{
*Corresponding author: herdis@ui.ac.id
} 
However, despite the transmigration scheme initiated by the Government since 1905, Java and Bali continued to grow at a much faster rate than transmigration rates. It has been proven not an easy task to create new viable settlements in remote areas [3]. Transmigration development is basically an implementation of a population policy that does not just move the population. In new places, the quality of life for refugees improves. They must get appropriate services to meet their needs [4], while human resources (population) have a strong relationship with a country's workforce [5] as an integral part of efforts to accelerate development. Meanwhile, improving the quality of human resources plays a role in reducing disparities between regions [6].

The success of implementing the transmigration program can be marked by the establishment of 2 new provincial capitals in Indonesia, namely Mamuju Regency and Bulungan Regency [7]. As the capital of the youngest province in Indonesia, Bulungan Regency has several missions to accelerate regional development. Among the missions launched is to adopt the Transmigration program to support food security [8]. The implementation of the transmigration program in Bulungan Regency which has been going on since the era of the Five Year Development Plan (REPELITA) shows the characteristics of the community which are quite open to the presence of newcomers. It was noted that the first transmigration location to be built in Bulungan District was the Gunung Putih transmigration location in Tanjung Palas District in 1973-1976, totaling 195 transmigrant families with a total of 908 people [9]. This research aims to reveal the contribution of the Transmigration program in Bulungan Regency (especially in the Salimbatu Transmigration Area (KTSb) which is an integral part of the Delta Kayan Food Estate (DeKaFe) which is expected to boost the level of the regional economy, especially in the agricultural sector by using the research concept framework in Fig. 1. This research is important because according to data from the Central Statistics Agency of Bulungan Regency, even though the agricultural sector still occupies ranked second largest in terms of supporting the regional economic foundation, but the emerging trend shows a decline from year to year since 2016 $[10]$.

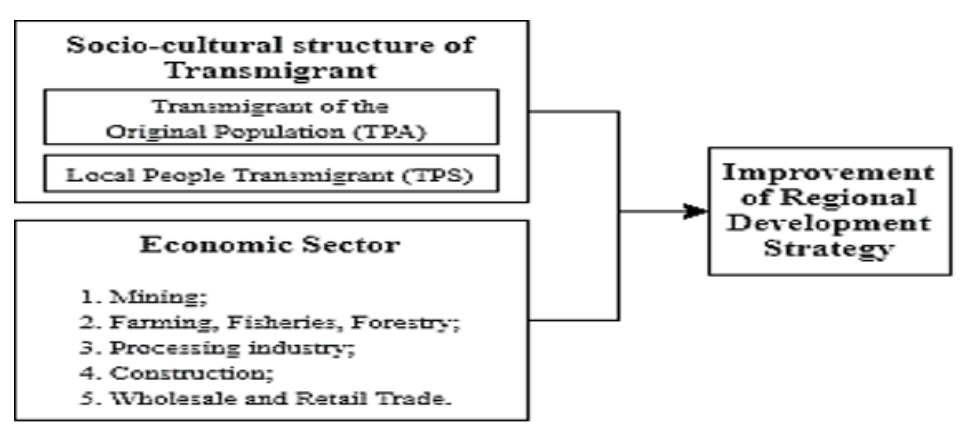

Fig. 1. Research concept framework.

\section{Method}

This article is prepared with a quantitative approach to reveal the details of the research object by referring to the data (literature study) published by the relevant agencies in the form of statistical data and reports in narrative form. The macro data was then dissected to determine the socio-cultural profile of the Bulungan Regency community. The detailed socio-cultural profile is then analyzed to link it with data on trends in the agricultural sector, which is the main development issue in Bulungan Regency. The analysis carried out was also strengthened by the analysis of geographic information systems in order to obtain 
a more comprehensive and in-depth description of the research results related to the Bulungan Regency regional government policy strategy in the agricultural sector with transmigration. program.

\section{Results and discussion}

\subsection{History of the Bulungan Regency}

In terms of demographic aspects, the KTSb area is in the Bulungan Regency area and is an integral part of the former Bulungan Kingdom area (see Fig. 2). The Sultanate of Bulungan was a kingdom that developed from a group of Dayaks who settled near the coast and then moved from Apo Kayan in the 17th century along the Kayan River, settled near Long Peleban (middle Kayan, and then moved further downstream to the Binai River, Near the beach). The Community Story refers to the fact that this kingdom was built by migrants who had a mixed lineage between Dayaks, Malays (Brunei) and Indians who later built settlements near Tanjung Selor with the style of the Islamic kingdom [11]. So, it can be understood that the more modern Bulungan people are those who are bound by a descendant of the ethnic Hupan or Dayak Kayan, who have been mixed and influenced by Islamic religious traditions and are under the authority of the Bulungan Sultanate [12].

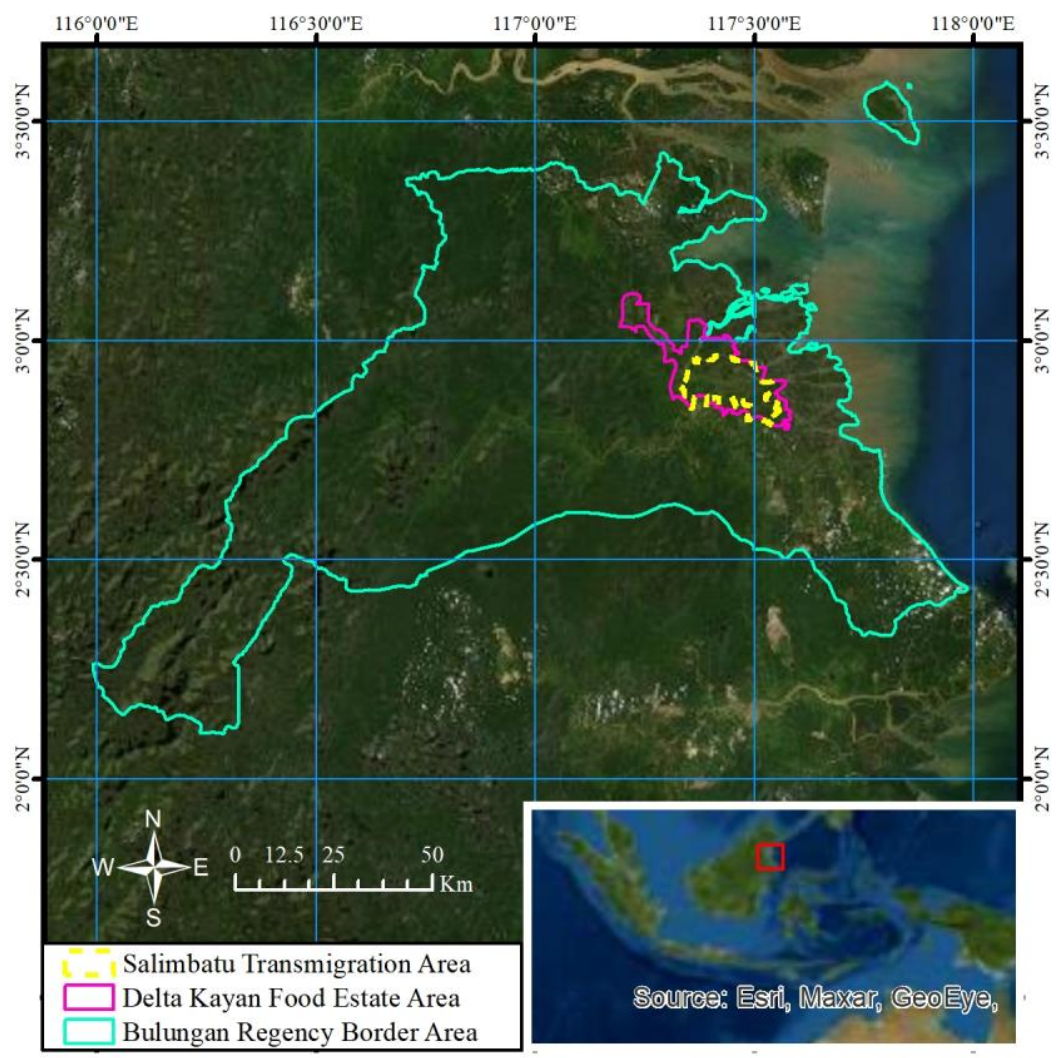

Fig. 2. Position of the Salimbatu Transmigration Area towards the Delta Kayan Food Estate and Bulungan Regency. 
Based on this historical quote, then the Bulungan community was identified as a distinct tribe from the original Dayak community of Kalimantan as the Bulungan tribe. The Bulungan tribe is a tribe of speakers conveying an event in an oral way (Oral Tradition) and only recognizes the writing of pure Arabic letters and Jawi letters (Arabic-Malay) after Islam entered (in the mid-18th century) [13]. After the independence of the Republic of Indonesia was successfully achieved, the Sultanate of Bulungan declared its entry into the sovereignty of the unitary state of the Republic of Indonesia. But a few years later an issue arose which stated that the Bulungan Sultanate wanted to get out of Indonesia and join Malaysia. Hearing this issue, the security controller immediately took decisive action by sending military forces to Bulungan. This then triggered the massacre of relatives and relatives of the Sultanate of Bulungan. Looting occurred, the historical legacy of the sultanate building was burned by an uncontrollable mob [14].

\subsection{Transmigrant community structure}

In a more focused scope on KTSb, based on the recapitulation of the development and placement of Transmigration in KTSb which started from 2003 to 2019 there were 3,858 Transmigrant Family Heads (KK) with a population of 14,538 transmigrants. The concept of implementing the Transmigration program which is currently being developed is to build locations and place the Transmigrant community with an estimated proportion of $50 \%$ Local People/ Transmigrants of Origin (TPA) who are residents from outside the placement area (outside Bulungan Regency) and 50\% Population/ Transmigrants Local Population (TPS) who are residents of the internal placement area (Bulungan Regency) (see Table 1 and Fig. 3).

Table 1. Recapitulation of the placement of transmigrants in KTSb based on regional origin [15-24].

\begin{tabular}{|c|l|r|r|}
\hline \multirow{2}{*}{ No. } & \multirow{2}{*}{ Place of Origin } & \multicolumn{2}{|c|}{ Amount } \\
\cline { 3 - 4 } & & Families & \multicolumn{1}{c|}{ Peoples } \\
\hline 1. & North Kalimantan & 1,935 & 7,902 \\
\hline 2. & East Java & 995 & 3,098 \\
\hline 3. & Central Java & 497 & 2,062 \\
\hline 4. & Yogyakarta & 213 & 686 \\
\hline 5. & West Java & 129 & 444 \\
\hline 6. & Lampung & 50 & 194 \\
\hline 7. & West Nusa Tenggara & 25 & 94 \\
\hline 8. & Banten & 14 & 58 \\
\hline & Total & 3,858 & 14,538 \\
\hline
\end{tabular}



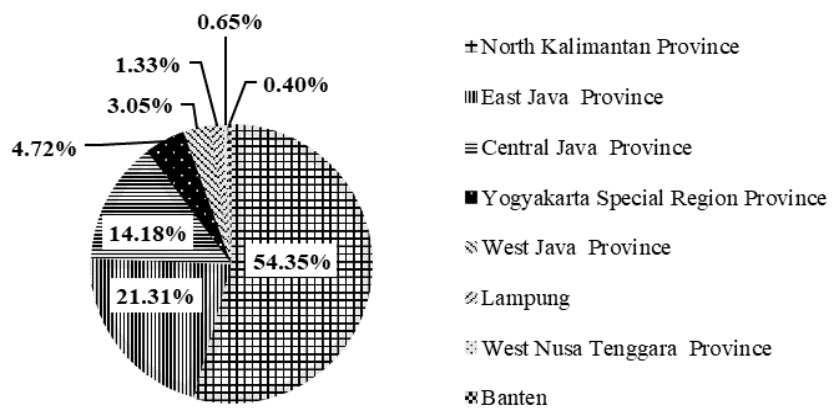

Fig. 3. Proportion of total population in KTSb by region of origin c.

At present the number of transmigration sites that have been built in the KTSb region is 12 out of 13 transmigration sites that have an existing population of 3.858 households (out of a total capacity of 4.584 households) or 14.538 transmigrants. As of 2003 , the intensity of the development and placement of Transmigrants in KTSb continues to increase (see Fig. 4). Until 2020, the level of fulfillment of existing capacity in KTSb has on average reached $77,30 \%$ of the optimal capacity of the KTSb plan.

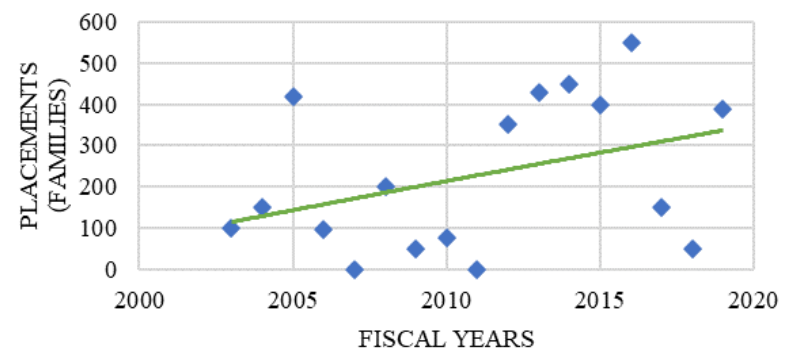

Fig. 4. Graph of the intensity of development and placement of transmigrants in KTSb [15-24].

\section{Conclusion}

Based on the findings of facts contained in various related literature, it appears that the open characteristics of the Bulungan customary community also influenced the level of development in Bulungan until they were appointed as the capital of North Kalimantan Province. Apart from that, this is one of the factors causing the rate of migration to the Bulungan area, which is now the capital of North Kalimantan Province. Although the socio-cultural proportion of the population (Transmigrants) of the Salimbatu Transmigration Area who comes from outside Bulungan Regency with a strong agricultural background reaches $46.65 \%$ of the total population, it is proven that it has not been able to make a significant contribution in increasing the capacity of the regional agricultural sector. This can be seen from the data on Transmigration placements which have an increasing trend but in proportion have actually decreased constantly since 2016 . If you look more specifically, the sectors that have actually increased since 2016 are construction, trade, government administration, land and land. social Security. This is a strong indication that there has been a shift in the sector that drives the economy in Bulungan Regency towards a center for goods and services, which is strengthened by a policy of massive physical development. Although the development and placement of transmigration has an increasing trend with the agricultural sector as the second largest sector, it has a continuing downward trend $[10,15-24]$. It is clear that the current socio-cultural infiltration with human resources 
with a strong agricultural background (transmigration) is still not sufficient to boost the contribution of the agricultural sector to the regional economy of Bulungan Regency. Therefore, to be able to implement the Transmigration program as an integral part of the food security system, a more structured and massive policy improvisation is needed.

\section{Acknowledgements}

This article is part of Sindhung Wardana's final research on the Environmental Science master program - Universitas Indonesia and is funded by the Master's Thesis Research Ministry of Research and Technology / National Research and Innovation Agency (KEMENRISTEK / BRIN) - Universitas Indonesia with contract number 8/ E1/ KP. PTNBH/ 2020 and 255/ PKS/ R/ UI/ 2020. Thanks to Fedhi Astuty Hartoyo for the support during the writing process.

\section{References}

1. Wicaksono E, Amir H and Nugroho A 2017 The Source of Income Inequality in Indonesia: A Regression-Based Inequality Decomposition ADBI Work. Pap. 1-16

2. Pribadi D O, Putra A S and Rustiadi E 2015 Determining optimal location of new growth centers based on LGP-IRIO model to reduce regional disparity in Indonesia Ann. Reg. Sci. 54 89-115

3. Hardjono J M 2017 Transmigration in Indonesia Pac. Aff. 51 532-3

4. Husodo S Y 2003 Transmigration Needs of Heterogeneous Populated Island Countries with Unequal Distribution (Jakarta: PT. Tema Baru)

5. Pratama S D and Rahadiana R 2019 The Evaluation of Indonesian Labour Market in Optimizing Demographic Dividend in 2016 JKAP (Jurnal Kebijak. dan Adm. Publik) 22 84

6. Panjawa J L, Samudro B R and Soesilo A M 2018 Regional Economic Disparities in Eastern Indonesia and Determinants: Comparative Analysis of Origin District and New District Reg. Sciece Inq. 10 117-24

7. Ditjen. PKP2Trans 2015 Transmigrasi Masa Doeloe, Kini dan Harapan Masa Depan (Past, Present and Future Future Transmigration) (Jakarta: Ministry of Village, Development of Disadvantage Area and Transmigration Republic of Indonesia)

8. Pemerintah Kabupaten Bulungan 2016 Visi, Misi dan Motto Kabupaten Bulungan Tahun 2016 - 2021 (Vision, Mission and Motto of Bulungan Regency for 2016-2021) 2019

9. Dinas Tenaga Kerja dan Transmigrasi Prov. Kaltim 2013 Realisasi Penempatan Transmigrasi Repelita 1 sampai dengan Tahun 2013 di Provinsi Kalimantan Timur (Realization of Repelita 1 Transmigration Placement to 2013 in East Kalimantan Province) (Samarinda)

10. BPS Kab. Bulungan 2020 Kabupaten Bulungan dalam Angka (Penyediaan Data untuk Perencanaan Pembangunan) (Bulungan District in Figures (Provision of Data for Development Planning)) 2020 (Bulungan: Badan Pusat Statistik Kabupaten Bulungan)

11. Sellato B 2001 Forest, resources and people in Bulungan ed C Kuhn (Bogor: Center for International Forestry Research (CIFOR))

12. Susanto N N 2016 Pengaruh Budaya Luar Terhadap Perkembangan Masyarakat Bulungan: Studi Pendahuluan* (The Influence of External Culture on the Development of the Bulungan Society: Preliminary Study *) Naditira Widya 6117

13. Suku Bulungan Makna Simbol-Simbol Komunikasi Budaya Dalam Adat Pernikahan Suku Bulungan. (The Meaning of Cultural Communication Symbols in the Customary Marriage of the Bulungan Tribe) (Universitas Muhammadiyah Malang)

14. indonesia.go.id 2020 Kesultanan Bulungan yang Enggan Berperang (The War-Reluctant 
Monthly Sultanate) Portal Inf. Indonesia. 1-9

15. Dinas Tenaga Kerja dan Transmigrasi. Prov. Kaltim. 2009 Program dan Realisasi Program Transmigrasi Otonomi Daerah 2003-2009 (Program and Realization of the Regional Autonomy Transmigration Program 2003-2009) (Samarinda)

16. Ditjen. P2KT 2010 Realisasi Penempatan Transmigran tahun 2010 (Realization of Transmigrant Placement in 2010) (Jakarta)

17. Ditjen. P2KT 2011 Realisasi Penempatan Transmigran tahun 2011 (Realization of Transmigrant Placement in 2011) (Jakarta)

18. Ditjen. P2KT 2012 Realisasi Penempatan Transmigran tahun 2012 (Realization of Transmigrant Placement in 2012) (Jakarta)

19. Ditjen. P2KT 2014 Realisasi Penempatan Transmigran tahun 2013 (Realization of Transmigrant Placement in 2013) (Jakarta)

20. Ditjen. PKP2Trans 2015 Realisasi Penempatan Transmigran tahun 2015 (Realization of Transmigrant Placement in 2015) (Jakarta)

21. Ditjen. PKP2Trans 2016 Realisasi Penempatan Transmigran tahun 2016 (Realization of Transmigrant Placement in 2016) (Jakarta)

22. Ditjen. PKP2Trans 2017 Realisasi Penempatan Transmigran tahun 2017 (Realization of Transmigrant Placement in 2017) (Jakarta)

23. Ditjen. PKP2Trans 2018 Realisasi Penempatan Transmigran tahun 2018 (Realization of Transmigrant Placement in 2018) (Jakarta)

24. Ditjen. PKP2Trans 2019 Realisasi Penempatan Transmigran tahun 2019 (Realization of Transmigrant Placement in 2019) (Jakarta) 